\title{
Data Management Meeting Material
}

National Cancer Institute

\section{Source}

National Cancer Institute. Data Management Meeting Material. NCI Thesaurus. Code C115607.

A collection of agendas, presentation materials, and other documents that are generated for attendees during a data management meeting. 